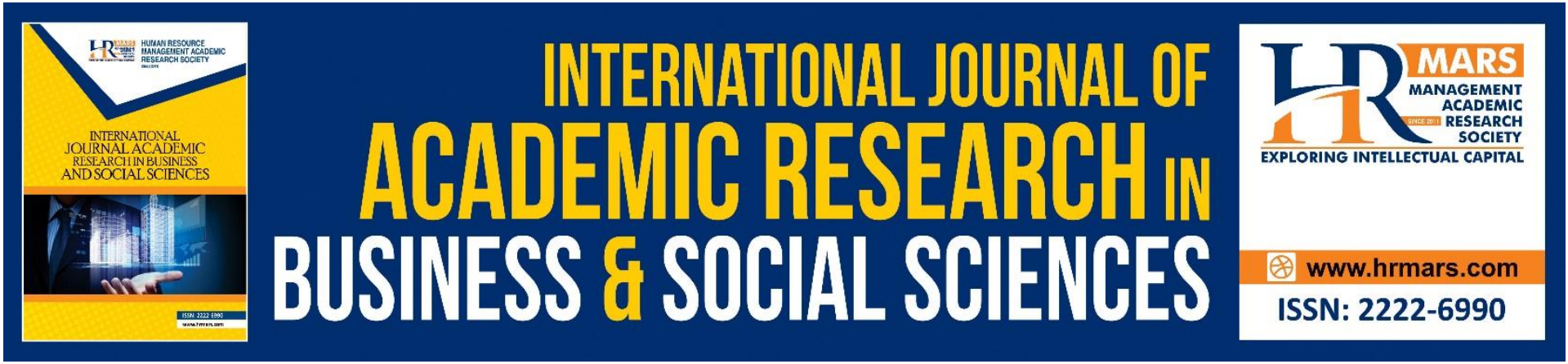

\title{
How Media Literacy Competency Contribute to Political Participation Integrity Among Young People
}

Siti Nurshahidah Sah Allam, Mohd Sufiean Hassan, Abdul Rauf Ridzuan, Rosilawati Sultan Mohideen \& Ilya Yasnorizar llyas

To Link this Article: http://dx.doi.org/10.6007/IJARBSS/v11-i4/9021 DOI:10.6007/IJARBSS/v11-i4/9021

Received: 11 February 2021, Revised: 15 March 2021, Accepted: 03 April 2021

Published Online: 26 April 2021

In-Text Citation: (Allam et al., 2021)

To Cite this Article: Allam, S. N. S., Hassan, M. S., Ridzuan, A. R., Mohideen, R. S., \& Ilyas, I. Y. (2021). How Media Literacy Competency Contribute to Political Participation Integrity Among Young People. International Journal of Academic Research in Business and Social Sciences, 11(4), 814-832.

Copyright: @ 2021 The Author(s)

Published by Human Resource Management Academic Research Society (www.hrmars.com)

This article is published under the Creative Commons Attribution (CC BY 4.0) license. Anyone may reproduce, distribute, translate and create derivative works of this article (for both commercial and non-commercial purposes), subject to full attribution to the original publication and authors. The full terms of this license may be seen at: http://creativecommons.org/licences/by/4.0/legalcode

Vol. 11, No. 4, 2021, Pg. 814 - 832

Full Terms \& Conditions of access and use can be found at http://hrmars.com/index.php/pages/detail/publication-ethics 


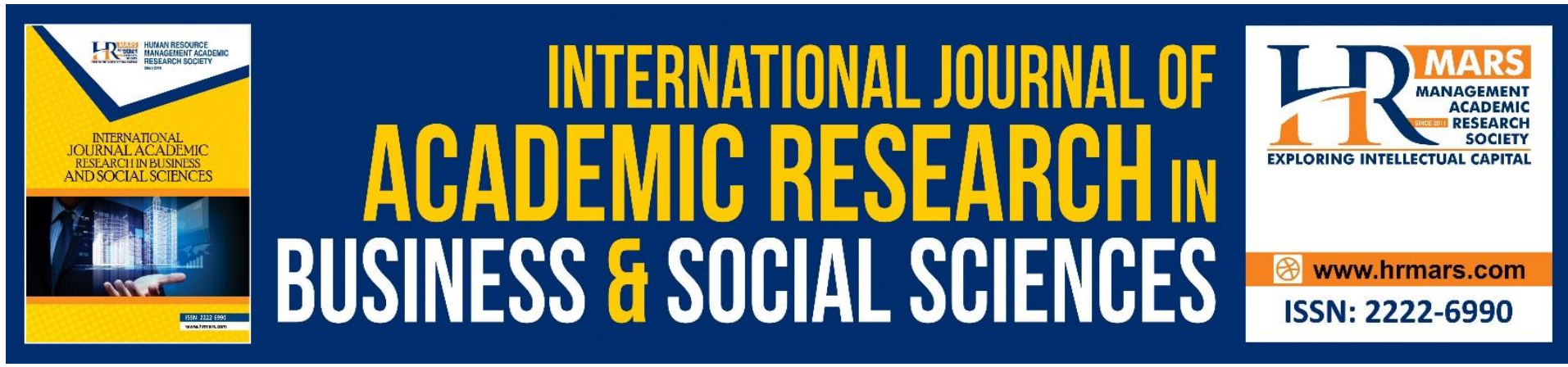

\title{
How Media Literacy Competency Contribute to Political Participation Integrity Among Young People
}

\author{
Siti Nurshahidah Sah Allam, Mohd Sufiean Hassan, Abdul Rauf \\ Ridzuan, Rosilawati Sultan Mohideen \& Ilya Yasnorizar llyas \\ Universiti Teknologi MARA, Melaka Branch, Malaysia
}

\begin{abstract}
Emerging social media reported escalating political participation among young people in social media and stimulate their interest to become a media content producer. Young media content producer with the usage of multimedia applications such as producing political parody, designing persuasive information graphics to create a new perspective on political issues. However, exposing multiplatform political information significantly affects integrity conduct where it drives them to create and disseminate fake information, digital trace, create deep fake and produce online humour to create damage on politician reputation. Unquestionably, all political involvements mention lead young people to commit to domestic crime. A survey conducted for data gathering among 388 Higher Education Institution (HEI) students in Melaka to provide an empirical understanding of media literacy contribution towards political participation integrity. This study found that access, analysis and evaluate and create dimensions significantly influence the integrity of political participation among young people. HEl students keen to become young media content producer by reason of easy access to multiplatform media, analysing media content enhance their political knowledge and create media content for new political perspective and communicate them through social media to seek for social change.
\end{abstract}

Keywords: Media Literacy, Political Participation, Integrity, Young Media Content Producer

\section{Introduction}

Emerging new media are now reported to increase political participation among young people in social media (Boulianne, 2015; Hassan et al., 2016). Vast research claimed that social media are now the most common platform for young people to access political information (Valenzuela, 2012; Vromen et al., 2014; Leong, 2015; Hassan et al., 2013), signing in political discourse (Kasmani et al., 2014) and getting engage online political activities (Valeriani \& Vaccari, 2016) that strengthening political interest and empowering their roles in national development (Holt et al., 2013). Determined by technological developments in communication and rapid user access to information the applications such as Facebook (Tang \& Lee, 2013), Youtube (Emruli et al., 2011), Twitter (Ahmed, 2013), weblogs (Willnat et al., 2013), and social networking sites (Stephens et al., 2014) have become vital influences for young people become young content media producer. 
Compared to conventional media such as newspaper, television and radio (Dauda et al., 2016), access to social media significantly influences young people interest due to multimedia tools offered interactive communication (Kang et al., 2007) and reach a mass audience (AlKandari \& Hasanen, 2012). Creating media content through multimedia applications such as producing audio and video for political parody content (Baumgartner, 2007) designing creative and persuasive information graphic to create a new perspective on political issues, creating animation and political cartoon for humour (Kuipers, 2011) approach reported young people rating as a famous social media influencer who create viral content (Berger \& Milkman, 2012). By becoming active media users, young people learn the practice of propaganda which essentially is a matter of creating highly attention-getting (Hobbs \& Mcgee, 2008) and effective communication (Kasmani et al., 2014) that leads people to some form of action (Boykoff \& Carrington, 2019). This intellectual initiative by young producers act as a catalyst for a civic movement (Kumar \& Thapa, 2014) or even low integrity action in a new political sphere across a large region (Hassan et al., 2019).

Access to hypermedia content claimed by preceding scholars expose young people to the low level of political activities that drive them to domestic violence (Bell et al., 2013) and cybercrime such as spreading rumours and fake news (Tucker \& Guess, 2018). According to Syahputra (2019), creating hatred on social media are initially understood as an expression of freedom of speech (Maamari \& Zein, 2014) in the contemporary democratic era. Afterwards, such expressions have been exploited as a means of conducting a provocation campaign during elections and this study found that various hate speeches regarding politics (Chinnasamy \& Abdul Manaf, 2018) and religious beliefs on social media due to an issue bearing controversial content and an opinion provoking or containing expressions of hatred.

Apart from that accessing provocation social media platform and using negative political news stimuli young people joining the massive demonstration (Zhang \& Lin, 2014), protest behaviour (Boykoff \& Carrington, 2019), creating humour political scandal (Ridanpaa, 2014) and spreading fake news (Dell, 2018) that driven yang people to commit a domestic crime. Today, as a young producer who makes use the advancement of technology; deepfakes (Westerlund, 2019), creating fake audio, video (Davies et al., 2013) and more exactly, the activity of social media 'faking' shows playful and performative (Wilson, 2011) reported not only demoralize politician's image and personality but sued national security (Kelley \& Laurie, 2019). Access to social media perceives to be a cause of troubles but with media education (Bober et al., 2010); Media Literacy dimensions suggested as a solution (Aufderheide, 1992; Hobbs, 2010; Livingstone, 2014; Potter, 2004) for young people to enhance integrity conduct in using media for political engagement (Bakker, 2007)

This impactful study conducted to integrate media literacy dimensions, especially access, evaluate and create towards political participation to reinforce integrity level among young people in social media (Hassan et al., 2020a). Prior study proves that media literacy dimensions successfully shape civic engagement (Martens \& Hobbs, 2015) among young people (Mihailidis, 2014) but little study quantifies the contribution for each media literacy construct toward political participation integrity to develop young media content producer. The purpose of this study is to examine access, evaluate and create dimensions concerning enhance integrity values among young people in social media. This study provides empirical discussion to strengthen understanding of media literacy competency connection to enhance political participation integrity among young people. 


\section{The New wave of Technology Evolve Media Literacy Dimensions}

Issue of media literacy has engrossed the attention of a wide range of intellectuals across almost all areas of study and even throughout the society who concerned about young people that exposure to the risk of media impact. The idea of media literacy competency is vital for society to use media ethically and with integrity conduct. The changes in the wave of technology in media and communication transform media literacy definition and dimensions.

Early literacy coined due to measuring the ability of the community reached and read a book as the main medium to gain knowledge and information. The invention of the technology of media from print to screen reported burst phenomenon known as media effect. The issues started from newspaper publication contained sensational news, television advertised violent and sexual content urged media scholars to integrate the new dimension of literacy known as media literacy by observing media content and audience behaviour. Many social scientist scholars adapt media literacy concept by Aufderheide (1992) presented a media literacy framework in National Leadership Conference on Media Literacy as "The ability to access, analyze, evaluate and communicate messages in a variety of forms."

However, according to Johnson \& Kaye, (1998) who study on web users enhance media literacy concept from the access dimension into competency to identify credible platform in social media for political information searching. The new media unfiltered flow of information causes their credibility is questionable. A framework of media credibility highlighted based on fair journalism, accurate source of information and in-depth reporting.

Despite from access to use media and media credibility, another construct expands due to wave of technology development from the media literacy dimension is create that refers to the ability to produce multimedia content (making text, images, audio and video) and publish for the online community (AMLA, 2007). The vast study labelled to young people as media content creators as user-generated content, new media content creator, sophisticated user, active media creator, produsage and young producer.

The development of media technology witness enhancement of media literacy definition and dimensions. Study on media literacy not only observing media access and media use among young people in social media but need to consider the competency level. By analysing media credibility and ability to create content, young people reported can effectively make use of multimedia tools access in social media.

This study defines media literacy as an ability to access media platform and media tools, evaluate media message to ensure media credibility and create media content for social movement and social change. All elements highlighted is to integrate media literacy dimension and political participation integrity in social media among young people.

\section{Political Participation Integrity Develop Young Media Content Producer}

Access to political information in social media exposing young people to political knowledge that reported contain high political cynicism information. A young people who reported extremely active media content producer than an adult due to their intense to explore new tools and applications in social media, in-group with technology savvy, creative and passionate on new applications expose to negative political information during searching unfiltered multiplatform information in social media.

Utilize unfiltered information on social media, young people who expose to low credible media content significantly influence to produce provocation content. Lack of analysis and evaluate competency to search credible media sources, young media content producer reported to have limited exposure to political knowledge and their judgement tends to be 
biased, little in-depth discussion and little fairness political view. This scenario develops political cynicism sentiment among young people that drive their low integrity participation in political activities such as create and disseminate fake news, digital trace, create deep fake, using trolls (anonymous accounts created for manipulation), bots (automated accounts) to spread politically biased information and produce online humour to create a negative image of a political entity easier than conventional media. Unquestionably, all negative political activities mention leading young people to delinquency behaviour and more seriousness they lodge to commit to domestic crime and cybercrime.

Concerning low political participation integrity affect social stability, the national security and country movement development, social scientist scholars believe that media literacy competency provides effective guidelines in engaging political activity among young people in social media. Media literacy highlighted an ability to access to credible media, evaluate media messages and create media content shape young people ideology as a media content producer become more ethically and align with integrity conduct. There are three media literacy dimensions highlight in this study, 1) access, 2) evaluate and 3) create.

\section{New Access Dimension for Credible Sources}

Access dimension highlighted preliminary competency for young people to search political information through multiplatform media in social media. High access to political information reported as young people possess greater political knowledge (Wolfsfeld et al., 2015) that influence political interest to get engage in political activities (Sah Allam et al., 2012) in social media (Hassan et al., 2016) and become young media content producer.

Nowadays, social media offers multiplatform communication medium derived from motivation needs to get access to political knowledge (Gil de Zúñiga et al., 2012), selfexpression (Bektas, 2009) to get engage to online political community groups and feeling convenience accessing online political information (Kim \& Johnson, 2012).

Supported by (Casero-Ripollés, 2017) who study on media access and intention to produce political content among young people in Spain found that access to social media vital element for young people become a political content producer by accessing political information for political knowledge (Kaid et al., 2007), easy access to a mass community to gratify political inclination (Velasquez, 2012) and access to political parties media to share political interest (Kim \& Johnson, 2012).

A vast study reported that media literacy on the access dimension significantly influences political knowledge (Pires et al., 2019) and stimuli young people interest for political participation (Hassan et al., 2013) become young media content producer. Ethical content media producer must competent to differentiate credible sources.

According to Kim \& Johnson (2012), access to political blog develops high level to credible sources where political bloggers occasionally provide critical view and deep analysis for certain issues. Apart from that, political bloggers encourage young people to gratify their political inclination to freely express their political judgement, political opinion (Greuling \& Kilian, 2014) and communicate it to other in-group members. Provide critical political view and credible sources platform (Rill \& Cardiel, 2013) strengthening young people understanding on political issues (Park, 2015) reported access to weblog significantly enhance political participation integrity among young people (Bakker, 2007). To ensure our young people involved in political activities in high integrity conduct, this study suggests that access to multiplatform media, credible media sources, ethical-political figures, critical and analytical political information that enhance young people understanding on certain political issues. 
Access to all elements promises high integrity level of political participation among young people in media social.

H1: There is an effect between the access dimension and political participation integrity among young people in social media

\section{Analysis and Evaluate Dimension Develop Critical Young Media Content Producer}

Access to multiplatform media, credible sources, political figures and critical political information significantly develop analysis and evaluate the competency among young people (Hassan et al., 2020). According to Aufderheide (1992), the most influential scholar in Media Literacy define analysis and evaluate dimension as a media user who able to analyse and evaluate media content that she is actively transferring meaning.

By having this competency, young people become an active media user/viewer who can produce their content from critically evaluate media content. Supported by Hobbs (2010) who define analysis and evaluate competency refers to the mentally critical user, practice message composition and creativity and the ability to engage in ethics. When someone has media literacy they will recognize the rights of others, their social responsibility and exercise their right to speak based on integrity (Aufderheide, 1992; Hobbs, 2010). How analysis and evaluate dimension contribute towards political participation integrity among young people in social media?

Young people who possess this competency must be able to identify credible media content (Murinska-Gaile \& Hadžialić, 2017). Many research has demonstrated that young people are highly depending on social media to access political news (Gil de Zúñiga et al., 2012; Hassan et al., 2013, 2016; Saldaña et al., 2015) to get political information rather than depending on conventional media such as newspapers or television.

How do we know if political information shared on social media is credible sources? By using this question as a foundation, young people must be able to analyse media content that free from negative bias information (Cohen et al., 1988), discussion in a social media without oppression and fears of exclusion (Alvídrez \& Franco-Rodríguez, 2016) and stereotyping information (Simmons, 2019). Besides, political information contains on social media reported developing a high level of credible sources by providing a critical view and deep analysis (Kim \& Johnson, 2012) to feed political knowledge for social media users, especially young people who keen become young media content producer.

Even though political information in social media treated freehand from the editorial process, young media content producer enhance their political participation by sharing their valuable political interest, political knowledge and political experience through social media for the online community. The content produces practice integrity conduct when they also rely on peer review by other media users to add and correct political information update (Aysan, 2016). Apart from that young people reported believing that social media more credible sources to rely on since they are independent rather than traditional media (Kim \& Johnson, 2012) who filtered away truth facts to face-saving behaviour for corporate agenda.

By choosing credible content, young people went through the process of analysing and evaluating information. This is how media literacy enhances young people political participation integrity in media social. As well as evaluating credible content, in the digital age young people has a variety of selections when searching for information. They must be able to search multiplatform media to analyse political information update on social media for clarity to strengthen integrity level conduct. The more critical analysing level that young 
people have, the high level of credible content they earn and significantly influence high political participation integrity level and become young media content producer.

This study conducted to measure analysis and evaluate dimension contribute toward political participation integrity among young people in media social. From elements of credible sources and multiplatform media for information seeking, analyse and evaluate dimension expected can strengthen integrity conduct in engaging political activities in social media.

H2: There is an effect between analysis and evaluate dimension and political participation integrity among young people in social media

\section{New Create Dimension: Create Integrity Participatory Culture for Social Movement}

Media literacy perspective provides ethical guidelines for young people to use media. Access to multiplatform media and able to use a variety of media tools associate their competency in working with media. Apart from that young people possess analyse and evaluate skills to compare much political information (Hobbs, 2017) in social media that must contain credible sources elements (Ashley et al., 2010) before using it. Besides, young people must know how and where to search multiplatform media for political information searching to earn a critical and analytical political view.

Completed the stages, young people expected to become active media user, usergenerated content (Van Dijck, 2009), content creator (Blank, 2013), generation of content producer (Vainikka \& Herkman, 2013), produsage (Naab \& Sehl, 2017), a sophisticated user (Brandtweiner et al., 2010) or even young media content producer (Young et al., 2014) to create and craft media content. Young media content producer expected to understand the art of combining texts, images, video (Mihailidis \& Cohen, 2013) and to create an ethical participatory culture among the online community (Buckingham, 2005). Supported by (Mihailidis, 2014), young people taking separate roles seen as active participants who interact with others through content that they produce and calling attention to the online community to participate political activities such as online forum and discussion.

Producing media content from analytical competency, young media content producer predicted to create a new angle of political information (Hobbs \& Mcgee, 2008), a new perspective of political knowledge and communicate them to the online community (Kümpel et al., 2015) for online participation that leads to a social movement. According to ChanOlmsted et al., (2013) who conducted an empirical study among young people in South Korea found that social media facilitate main political information sources from political discourse (Kasmani et al., 2014) and effective platform for political expression (Yamamoto \& Kushin, 2014) which in turn to call protest participation for social movement and social change (Ahmed, 2013).

By producing critical opinion, educated young media content producer expected to produce ethical content to neutralize negative political movement and develop integrity conduct among the online community (Hassan et al., 2020). Live positive comments, correcting misinformation or disinformation disseminate in social media, abandon from sharing viral or fake news, media literacy from creating dimension reported enhance integrity conduct among young media content producer and create social movement follow integrity conduct.

Even though young people are actively involved online political activities, there is also significant evidence that many of them are mostly disengaged from political activities, rarely 
create and circulate political content (Kahne \& Bowyer, 2019). But, young people in Higher Education Institution reported highly confident to create political content due to the knowledge gain during learning sessions.

Preliminary factors need to be considered by researchers who examine critical young producers who create political content in social media is education level. Stockemer (2012) discover the student's program of study, year of study, academic performance, and field of study affect young people political interest that increases his or her likelihood to become media content producer in social media (Bullen, 2015).

The notion of discussion on how education influence young people create political content in social media started from the level of education become the proxy of political interest (M. Persson, 2013). Experiencing political syllabus and academic discourse moderated by academic scholars reported developing young people political interest (Parrott, 2017) that lead to analysing political knowledge and create political content in social media for political participation integrity.

H3: There is an effect between create dimension and political participation integrity among young people in social media

\section{Research Methodology}

The respondents of this study were 388 Higher Education Institutions (HEI) students comprising four universities in Melaka, Malaysia. Melaka was chosen due to political tsunami (GE-14) caused dramatically changes of state government political ruling. Student selection was based on random sampling. This study use questionnaires as a means of collecting data. Based on the number of respondents ( $n=388$ ) with complete data in this study, the sample size is large enough for the use of Structural Equation Modelling (SEM) (Hair et al., 2010). Before proceeding to the final data collection, pilot study to test the reliability of the instrument was conducted to ensure the consistency of the questionnaire. Cronbach Alpha's reliability coefficient for all four variables, above 0.70 , shows a good internal consistency (Hair et al., 2010). The adapted instrument was reviewed by an expert and a pilot test was conducted to determine the validity of the items. The aim of this study is to identify indicators of media literacy scale using Exploratory Factor Analysis and to identify structural measurement model using Confirmatory Factor Analysis (CFA).

\section{Research Instrument}

The questionnaire consists of two parts used as the instrument of this study. Part A consists of general information on demographic variables such as gender, age, status, race, education and social media usage. Part B contains a media literacy scale adapted from Mustafa Koc dan Esra Barut (2016), then translated into Malay. The scale to measure media literacy is a wellestablished scale that has proven its reliability because it is widely used in past studies. Reliability cronbach alpha for all five media literacy are between $0.89-0.92$. The steady use of the scale actually helps in terms of the reliability of the scale in gaining information through the public (Babbie, 2013). This scale contains 33 items and is measured using a seven-level interval scale of 1 = strongly disagree to $7=$ strongly agree. This measurement scale measures access, analysis and evaluate and create. 
Table 1. Dimension of Media Literacy and Cronbach Alpha

\begin{tabular}{|c|c|c|c|}
\hline $\begin{array}{l}\text { Dimension of } \\
\text { media literacy }\end{array}$ & Research Instruments & Operational Definition & $\begin{array}{l}\text { Cronbach } \\
\text { Alpha }\end{array}$ \\
\hline Access & $\begin{array}{l}\text { New Media Literacy } \\
\text { Scale (NMLS) Mustafa } \\
\text { Koc dan Esra Barut } \\
(2016)\end{array}$ & $\begin{array}{l}\text { Access refers to individuals } \\
\text { should have the skills to access } \\
\text { political information } \\
\text { efficiently on social media } \\
\text { networks (sign ups, logins and } \\
\text { sent messages) and using } \\
\text { social media (uploading and } \\
\text { downloading videos, editing } \\
\text { photos, etc.). }\end{array}$ & .92 \\
\hline $\begin{array}{l}\text { Analysis and } \\
\text { Evaluate }\end{array}$ & $\begin{array}{l}\text { New Media Literacy } \\
\text { Scale (NMLS) Mustafa } \\
\text { Koc dan Esra Barut } \\
\text { (2016) }\end{array}$ & $\begin{array}{l}\text { Analysis and evaluate refers } \\
\text { to the ability to determine } \\
\text { whether the content of } \\
\text { political information on social } \\
\text { media is ethical, moral, } \\
\text { integrity by comparing } \\
\text { political information from one } \\
\text { source to another on social } \\
\text { media. }\end{array}$ & .92 \\
\hline Create & $\begin{array}{l}\text { New Media } \text { Literacy } \\
\text { Scale (NMLS) } \text { Mustafa } \\
\text { Koc dan Esra Barut } \\
\text { (2016) }\end{array}$ & $\begin{array}{l}\text { Create refers to the activity of } \\
\text { creating an account and filling } \\
\text { out profile information, } \\
\text { creating interactive political } \\
\text { content on social media } \\
\text { through up-to-date and } \\
\text { authentic data such as } \\
\text { statistics, archive documents. }\end{array}$ & .89 \\
\hline
\end{tabular}

\section{Data Analysis}

The data were analyzed by using descriptive statistic to describe the respondent profile of the study and exploratory factor analysis (EFA) with IBM SPSS 22.0 software. Analyzing EFA is an important foundation for strengthening the construction of constructs (Schumacker \& Lomax, 2010). The main use of EFA is to reduce the number of items and to detect the relationship structure between items that make up the construct dimension (Hair et al., 2010). In this study, principal component analysis with varimax rotation is used to determine the number of components.

AMOS 21.0 software was used to perform Confirmatory Factor Analysis (CFA). The CFA aims to determine the number of items included in the constructs in parallel with what is stated in theory (Byrne, 2016). The accuracy of the CFA model matching is determined by a combination of at least one Absolute Fit Indices and one Incremental Fit Indices (Hair et al., 2014) and Parsimony Fit Indices (PFI) (Hair et al., 2010). The test on CFA is used to determine whether the tested model should be accepted or rejected. However, there is no specific rule that determines whether a compatibility index needs to be reported for a model (Hair et al., 
2010; Hooper et al., 2008). The use of three or more compatibility indexes is sufficient to prove a model fit, without to report all existing fit indexes (Hair et al., 2014).

\section{Findings}

\section{Exploratory Factor Analysis (EFA), Media Literacy}

The media literacy measurement scale tested consists of five constructs namely access, analysis and evaluate, create, reflect and act, all containing 33 items. The Kaiser-Meyer Olkin Measure of Sampling Adequacy (KMO) value $=0.942$ exceeds the value of $>0.6$ to meet the factorial requirements (Hair et al. 2010). While the value of Bartlett's Test was significant ( $p$ $<.05)$. This indicates that the items used in the Exploratory Factor Analysis of this study had good inter-correlation strength among each other. Table 2 shows the results of the construct matrix correlation.

Table 2. Media Literacy Correlations Matrix

\begin{tabular}{lll}
\hline $\begin{array}{l}\text { Kaiser-Meyer-Olkin } \\
\text { Adequacy. }\end{array}$ & Measure of Sampling & .942 \\
\hline Bartlett's Test & of & Approx. Chi-Square \\
Sphericity & & 9775.983 \\
& df & 528 \\
& sig. & .000 \\
\hline
\end{tabular}

According to Hair et al. (2010), items with low loading factor from 0.50 should be removed. In this study, all items accepted due to factor loading greater than 0.50 , which are in between 0.523 to .974 . To test convergent validity, researchers use Average Variance Extracted (AVE) and Construct Reliability (CR). According to Hair et al. (2010), the AVE value should be greater than 0.5 and CR is greater than 0.7. Based on AVE's decision for access, analysis and evaluate and create these three constructs exceeded 0.5 . The reliability value of all five latent variables (constructs) ranges from 0.866 to 0.925 , greater than 0.70 , shows that Cronbach's alpha is in good condition. The discriminant validity is to measure one construct with another construct and should not have a high correlation. Byren (2010) suggests that the value of $r=0.90$ or more indicates that the variable has a high correlation. Since the correlation findings in Table 3 show values in between 0.785 to 0.831 , this means that there is no high correlation problem (multicollinearity).

Table 3. Average Variance Extracted, Constructs Reliability and Correlation

\begin{tabular}{lllllll}
\hline $\begin{array}{l}\text { Laten Variable } \\
\text { (Constructs) }\end{array}$ & CR & AVE & A & Access & Analysis and Evaluate & Create \\
\hline Access & 0.866 & 0.620 & 0.968 & $\mathbf{0 . 7 8 7}$ & & \\
Analysis and Evaluate & 0.925 & 0.639 & 0.930 & 0.612 & $\mathbf{0 . 8 0 0}$ & \\
Create & 0.902 & 0.647 & 0.958 & 0.435 & 0.641 & $\mathbf{0 . 8 0 5}$ \\
\hline
\end{tabular}

Note: $\mathrm{AVE}=$ Average Variance Extracted, $\mathrm{CR}=$ Contsruct Reliability, $\alpha=$ Cronbach Alpha 
Table 4. Factor Loading Hypotheses to Constructs Indicators

\begin{tabular}{llll}
\hline \multicolumn{2}{l}{ Indication } & Construct & $\begin{array}{l}\text { Statistic } \\
\text { Loading }\end{array}$ \\
\hline AK1 & $\leftarrow$ & Access & $.906^{* * *}$ \\
AK2 & $\leftarrow$ & Access & $.961^{* * *}$ \\
AK3 & $\leftarrow$ & Access & $.947^{* * *}$ \\
AK4 & $\leftarrow$ & Access & $.873^{* * *}$ \\
AK5 & $\leftarrow$ & Access & $.535^{* * *}$ \\
AK6 & $\leftarrow$ & Access & $.824^{* * *}$ \\
AK7 & $\leftarrow$ & Access & $.562^{* * *}$ \\
AP1 & $\leftarrow$ & Analysis and Evaluate & $.929^{* * *}$ \\
AP2 & $\leftarrow$ & Analysis and Evaluate & $.974^{* * *}$ \\
AP3 & $\leftarrow$ & Analysis and Evaluate & $.963^{* * *}$ \\
AP4 & $\leftarrow$ & Analysis and Evaluate & $.819^{* * *}$ \\
AP5 & $\leftarrow$ & Analysis and Evaluate & $.862^{* * *}$ \\
AP6 & $\leftarrow$ & Analysis and Evaluate & $.832^{* * *}$ \\
AP7 & $\leftarrow$ & Analysis and Evaluate & $.821^{* * *}$ \\
PC1 & $\leftarrow$ & Create & $.523^{* * *}$ \\
PC2 & $\leftarrow$ & Create & $.598^{* * *}$ \\
PC3 & $\leftarrow$ & Create & $.906^{* * *}$ \\
PC4 & $\leftarrow$ & Create & $.957^{* * *}$ \\
PC5 & $\leftarrow$ & Create & $.716^{* * *}$ \\
PC6 & $\leftarrow$ & Create & $.864^{* * *}$ \\
PC7 & $\leftarrow$ & Create & $.827^{* * *}$ \\
\hline
\end{tabular}

*** Standardized Regression Weights significant level at the .001 (2 tailed)

Based on Table 4, all loading factors are significant at the level of 0.001 and above 0.5 for all indicators. In addition, high standard regression values (0.523 to 0.974 ) indicate that all measured indicators are significantly representing their latent variables - constructs.

\section{Confirmatory Factor Analysis (CFA) Media Literacy}

Model specifications include 33 items, seven items for access, seven items for analysis and evaluate, seven items for create, six items for reflect and six items for act. However, this model should be modified in order to improve the fit of this model represents the sample data or real data better. Modifications are made by reference to the modification index. As a result, items AK1 (.46), AK3 (.38), AK4 (.48), PC1 (.32) PC2 (.44) and PC5 (.36) in the model had to be removed due to low loading factors $<0.5$. Next, items with high Modification Indice (MI) and high correlation between the two items were also modified. According to Hair et al. (2014), if there is a high correlation between the two items, they can be combined to obtain a model fit. Whereas if the item is not theoretically supported, the model needs to be modified by removing either one items with lower factor loadings (Hair et al. 2014).

The measurement model in Table 5 shows a good data fit with eight indicators ( $\chi 2$, CMINDF, RMSEA, GFI, IFI, TLI, CFI and PGFI) as shown in Table 5. However, Marsh \& Hau (1996) Chi-square $(\chi 2)$ can be divided by degrees of freedom ( $d f=100)$ to evaluate model fit compared to using $\chi 2$ (CMINDF). If the CMINDF statistics count is less than the value of 5 , the fit of the data for the validation factor model is good (Marsh \& Hau, 1996). CMINDF for this measurement model is less than the value of 5 (CMINDF $=2.250)$. This shows a fairly good 
CFA model. Furthermore, the RMSEA value is 0.055 which is lower than .08 as suggested by Kline, (2010). The index coefficients in Table 5 are all greater than 0.90 show a good model fit (Byrne, 2016), and the PGFI value is greater than 0.5 (.660) which also shows a good model fit with data (Hair, et al., 2010). Eleven (11) items have been combined due to the high index value of the modification (M.I). Figure 1 shows the CFA Model for this study.

Table 5. Confirmatory Factor Analysis (CFA)

\begin{tabular}{lllllllll}
\hline Description & $\chi^{2}$ & CMINDF & RMSEA & GFI & IFI & TLI & CFI & PGFI \\
\hline Model CFA & 264.154 & 2.165 & 0.055 & .925 & .969 & .961 & .969 & .660 \\
\hline
\end{tabular}

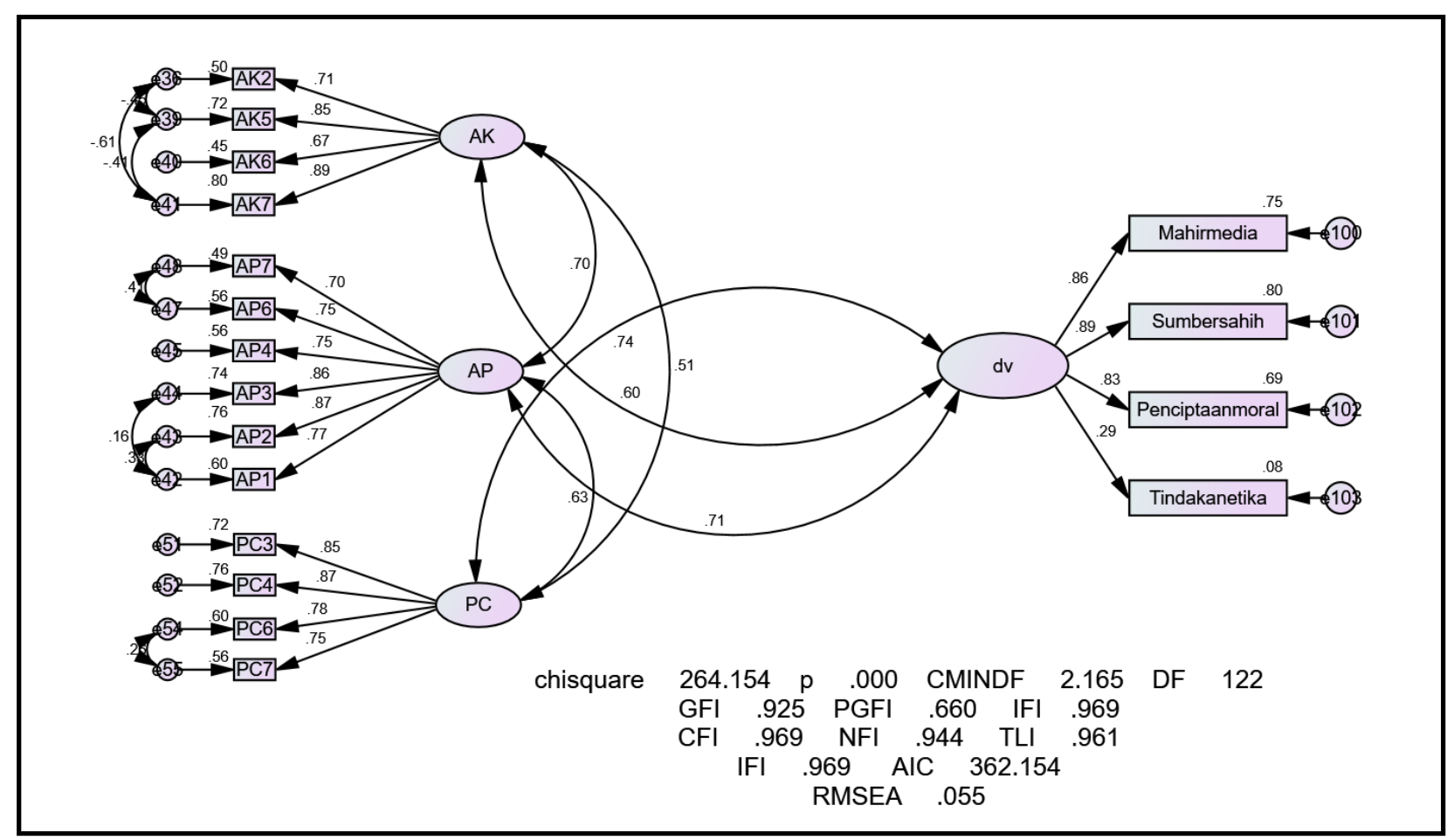

Table 6. Structural Equation Modelling (SEM)

\begin{tabular}{lllllllll}
\hline Description & $\chi^{2}$ & CMINDF & RMSEA & GFI & IFI & TLI & CFI & PGFI \\
\hline Full Model & 264.154 & 2.165 & 0.055 & .925 & .969 & .961 & .969 & .660
\end{tabular}




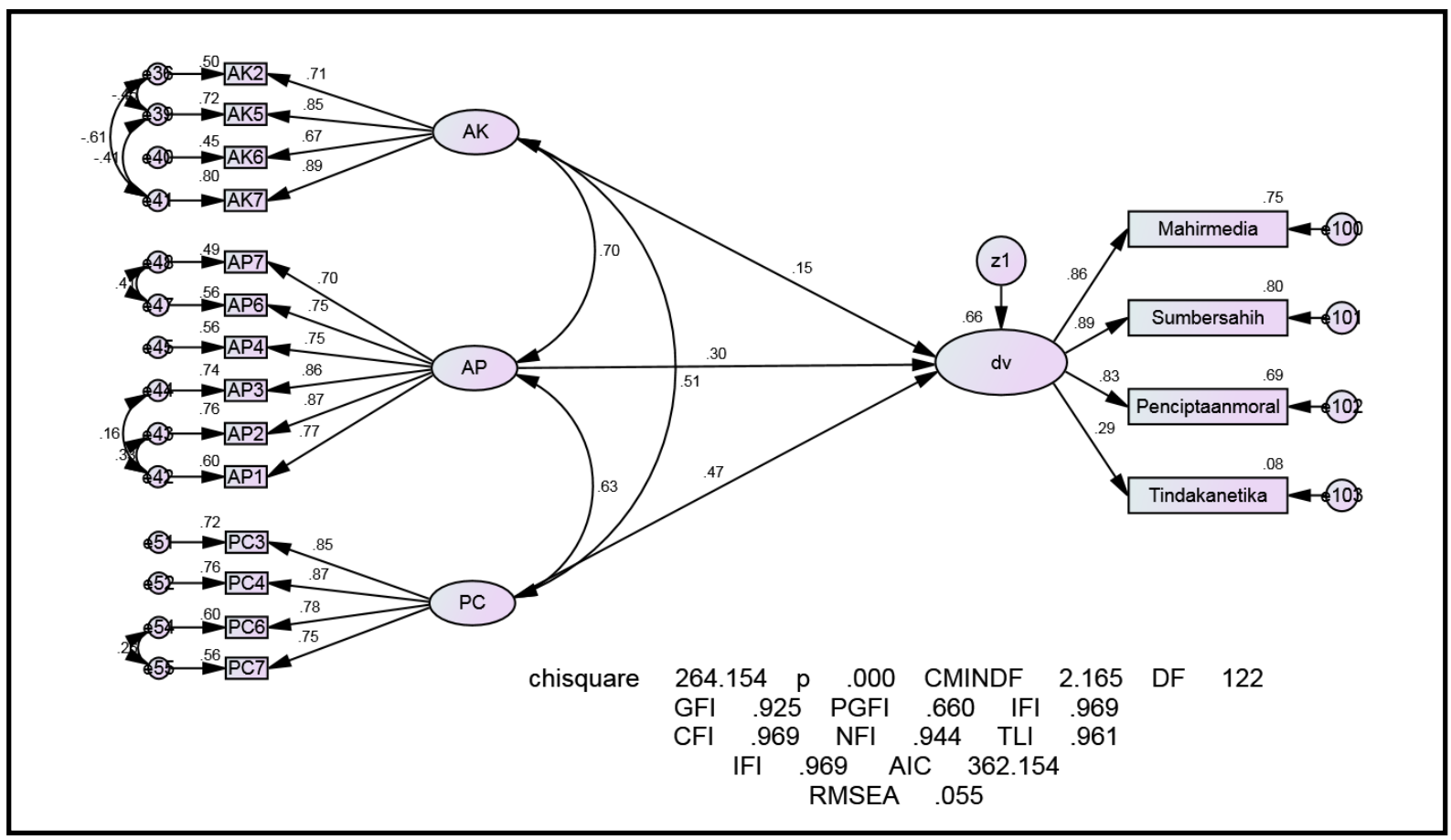

Table 7. Standardized Regression Weight) / Path coefficient of a structural hypothesis model of the integrity of political participation.

\begin{tabular}{|c|c|c|c|c|c|c|c|c|}
\hline \multicolumn{9}{|c|}{ Standardized Regression Weight) / Path coefficient } \\
\hline & & & & & Standard $(\beta)$ & S.E. & C.R. & $P$ \\
\hline $\begin{array}{l}\text { Political } \\
\text { Integrity }\end{array}$ & Participation & $<---$ & Access & & .15 & .419 & 2.802 & .005 \\
\hline $\begin{array}{l}\text { Political } \\
\text { Integrity }\end{array}$ & Participation & $<---$ & $\begin{array}{l}\text { Analysis } \\
\text { Evaluate }\end{array}$ & \& & .30 & .551 & 4.533 & $* * *$ \\
\hline $\begin{array}{l}\text { Political } \\
\text { Integrity }\end{array}$ & Participation & $<---$ & Create & & .47 & .501 & 8.001 & $* * *$ \\
\hline
\end{tabular}

\section{Discussion}

This study aimed to expand previous studies on the topic of media literacy and political participation among young people. We expected that media literacy would significantly affect political participation among young people. This study extended media literacy dimensions from education into political communication, and we modified the scale to analyze the effect, particularly in political participation integrity that little mention by the previous study. Surprisingly, media literacy dimensions significantly affect political participation integrity among young people. The finding of this study contradicts Ashley \& Maksl, (2017), who reported that media literacy from access dimension correlated with lower levels of political trust, and the findings indicate that media literacy is not associated with political participation. Access to more extraordinary political news leads to lower political trust, and Ashley \& Maksl, (2017) reported that media literacy does not affect political participation. They are testing media literacy based on Potter's cognitive model of media literacy (2004) in a different way on how Potter (2004) explains information and media where media as a transporter and the effect of using media highly affected with personal locus of media end user's. Media literacy skills reported significantly affected political participation integrity from access dimension. Access to media expose the volume and frequency of media messages is 
so overwhelming that most young people who have media literacy skills are be able to identify fake information. Study by Jones-Jang et al., (2021) found that media literacy skills are significantly increases the likelihood of identifying fake news stories. The ability of young people to access and find validated and accurate content online from a variety of sources is referred to as media literacy skills. The ability to access information especially political knowledge reported to young people political interest and enhance their political participation.

Greater information available in various platform in social media are developing analysis and critical thinking skills. This leads to a significant relationship between analysis and evaluating dimension and political participation integrity among young people in social media. This idea supported by Mihailidis \& Thevenin, (2013) that develop a framework for media literacy as a core political skill for active and participatory citizenship. Mihailidis \& Thevenin, (2013) enhance media literacy develop critical thinker from analysis and evaluate dimension in the digital age. Media literacy is the core competency to motivate young people to be more active and engaged citizens. In today's new media age, the engaged citizen must understand the relationship between media as a sense of platform to connect community and democracy. This is includes critical and analytic approaches to media literacy and core understanding to empower individuals to have a voice and use it.

Young people empowerment in politics shaped by media and this idea aligned with many studies (Leung \& Lee, 2014; Muntaen \& Muntean, 2015; Heiss \& Matthes, 2016; Lailiyah et al., 2018; Allaste \& Saari, 2020). The result showed that young people have strong engagement with social media because this new media offers interactive features that are now available in conventional media such as television or newspapers. Besides, new media offer young people gratification through specific social media where they share the same interest and idea about political issues. They can voice their ideas for political attention and gain support from the same opinion netizens. Social media encourage young people to become a content creator, and many social media tools support their needs by offering not only texting tools. They can create and craft creative videos, animations, and infographics as their content that reflects political issues. By having more excellent media literacy skills, young people are expecting to create ethical content, and now, they are engaging actively in political activity. Political participation integrity coming into the place where young people blend their political involvement with media literacy skills.

\section{Conclusion}

In a nutshell, enhancing political participation integrity level and developing young people empowerment that significantly affected by Media literacy competency. The dimensions of media literacy measure in this study (access, analysis and evaluate and create) presented significantly have an effect on the political participation integrity among young people in social media and educated young people confidently become young media content producer to create new political sphere by initiating a social movement for social change. It is a little study to discuss the strength of media literacy skills that leads to political participation. Many studies focus on media literacy in education and curriculum aspects, but little concern to test this competency that potentially affects political participation among young people. This study enhances the previous finding by combining media literacy competency with leading to political integrity among young people. The findings of this study highly contributed to Malaysia Education Policy and Malaysian Communications and Multimedia Commission (MCMC) for media literacy education awareness among young people. Furthermore, this 
study highly contributes to the body of knowledge by enhancing media literacy concept by highlighting new access dimension for credible sources, analysis and evaluate dimension develop critical young media content producer. Apart from that this study drives to create understanding on new create dimension for social movement and social change. Recommendation for future researcher to explore young media content producer initiative in social media for social movement and social change. As well as media literacy competency, social control level suggested strengthening integrity conduct among young people in social media.

\section{Acknowledgement}

This work was supported by Internal TEJA Grant, UiTM Melaka, Malaysia (GDT2021/1-1).

\section{References}

Ahmed, S. (2013). Protests against \#delhigangrape on twitter: Analyzing India's Arab spring Kokil Jaidka. Journal of Edemocracy, 1(5), 28-58.

Al-Kandari, A., \& Hasanen, M. (2012). The impact of the internet on political attitudes in Kuwait and Egypt. Telematics and Informatics, 29(3), 245-253.

Alvídrez, S., \& Franco-Rodríguez, O. (2016). Powerful communication style on twitter: effects on credibility and civic participation. Comunicar, 24(47), 89-97.

Ashley, S., Poepsel, M., \& Willis, E. (2010). Media literacy and news credibility: does knowledge of media ownership increase skepticism in news consumers? Journal of Media Literacy Education, 2, 37-46.

Aufderheide, P. (1992). Media Literacy: A Report of The National Leadership Conference on Media Literacy. In Media Literacy in The Information Age Current Perspectives 6(2).

Aysan, F. (2016). The role of attachment styles, peer relations, and affections in predicting internet addiction. The Turkish Journal on Addiction, 3(3), 416-432.

Baumgartner, J. C. (2007). Humor on the next frontier: youth, online political humor, and the jibjab effect. Social Science Computer Review, 25(3), 319-338.

Bektas, M. Ç. (2009). Media literacy courses in faculties of communication in TRNC. Procedia Social and Behavioral Sciences, 1, 446-449.

Bell, S. R., Cingranelli, D., Murdie, A., \& Caglayan, A. (2013). Coercion, Capacity, And Coordination: Predictors of Political Violence. Conflict Management and Peace Science, 30(3), 240-262.

Berger, J., \& Milkman, K. L. (2012). What makes online content viral? Journal of Marketing Research, 49(2), 192-205.

Berinsky, A. J., \& Lenz, G. S. (2011). Education and political participation: exploring the causal link. Political Behavior, 33(3), 357-373.

Blank, G. (2013). Who create content? Stratification and content creation on the internet. Information Communication and Society, 16(4), 590-612.

Brandtweiner, R., Donat, E., \& Kerschbaum, J. (2010). How to become a sophisticated user: a two-dimensional approach to e-literacy. New Media \& Society, 12(5), 813-833.

Buckingham, D. (2005). The Media Literacy of Children and Young People. In Ofcom.

Bullen, J. O. P. (2015). Measuring social capital in five communities the journal of applied behavioral science. Journal of Applied Science, 36(October), 23-42.

Byrne, B. (2016). Structural Equation Modeling With Amos: Basic Concepts, Applications, And Programming. Routledge.

Casero-Ripollés, A. (2017). Producing political content for web 2.0: empowering citizens and 
vulnerable populations. El Profesional De La Información, 26(1), 13.

Chan-Olmsted, S. M., Moonhee, C., \& Sangwon, L. (2013). User perceptions of social media: a comparative study of perceived characteristics and user profiles by social media. Online Journal Of Communication \& Media Technologies, 3(4), 149-178.

Chinnasamy, S., \& Abdul Manaf, N. (2018). Social media as political hatred mode in Malaysia's 2018 general election. SHS Web of Conferences, 53, 1-12.

Cohen, J., Mutz, D., Price, V., \& Gunther, A. (1988). Perceived impact of defamation. Public Opinion Quarterly, 52(2), 161-173.

Croke, K., Grossman, G., Larreguy, H. A., \& April, J. M. (2015). Deliberate Disengagement: How Education Decreases Political Participation in Electoral Authoritarian Regimes (Issue 156).

Davies, I., Mizuyama, M., Ikeno, N., Parmenter, L., \& Mori, C. (2013). Political literacy in Japan and England. Citizenship, Social and Economic Education, 12(3), 163-173.

Dell, M. (2018). Fake news, alternative facts, and disinformation: the importance of teaching media literacy to law students. Ssrn Electronic Journal, 1-31.

Emruli, S., Zejneli, T., \& Agai, F. (2011). Youtube and political communication - Macedonian case. International Journal of Computer Science Issues, 8(4), 460-466.

Hair, J. F., Black, W. C., Babin, B. J., \& Anderson, R. E. (2010). Multivariate Data Analysis: A Global Perspective. Pearson: Upper Saddle River, $\mathrm{Nj}$.

Hair, J. F., Black, W. C., Babin, B. J., \& Anderson, R. E. (2014). Multivariate Data Analysis. Pearson Education Limited.

Hobbs, R. (2010). Digital and Media Literacy: A Plan of Action. Http://Www.Knightcomm.Org/WpContent/Uploads/2010/12/Digital_And_Media_Literacy_A_Plan_Of_Action.Pdf

Hobbs, R., \& Mcgee, S. (2008). Teaching about propaganda: an examination of the historical roots of media literacy. Journal of Media Literacy Education, 6(62), 56-67.

Hooper, D., Coughlan, J., \& Mullen, M. (2008). Structural equation modelling: guidelines for determining model fit. Electronic Journal of Business Research Methods, 6(1), 53-60.

Johnson, T. J., \& Kaye, B. K. (1998). Cruising is believing? comparing internet and traditional sources on media credibility measures. Journalism and Mass Communication Quarterly, 75(2), 325-340. 4

Kahne, J., \& Bowyer, B. (2019). Can media literacy education increase digital engagement in politics? Learning, Media and Technology, 44(2), 211-224.

Kaid, L. L., Mckinney, M. S., \& Tedesco, J. C. (2007). Introduction: Political information efficacy and young voters. American Behavioral Scientist, 50(9), 1093-1111.

Kang, I., Lee, K. C., Lee, S., \& Choi, J. (2007). Investigation of online community voluntary behavior using cognitive map. Computers in Human Behavior, 23(1), 111-126.

Kasmani, M. F., Sabran, R., \& Ramle, N. (2014). Can twitter be an effective platform for political discourse in Malaysia? A study of \#pru13. Procedia - Social and Behavioral Sciences, 155(October), 348-355.

Kelley, M. S., \& Laurie, A. H. (2019). Deep fakes and national security. Congressional Research Service, 1(1), 1-3.

Kim, D., \& Johnson, T. J. (2012). Political blog readers: predictors of motivations for accessing political blogs. Telematics and Informatics, 29(1), 99-109.

Kline, R. B. (2010). Principles and Practice of Structural Equation Modelling. The Guilford Press. Koc, M., \& Barut, E. (2016). Development and validation of new media literacy scale (NMLS) for university students. Computers in Human Behavior, 63(October 2016), 834-843. 
Kuipers, G. (2011). The politics of humour in the public sphere: Cartoons, power and modernity in the first transnational humour scandal. European Journal of Cultural Studies, 14, 63-80.

Kumar, R., \& Thapa, D. (2014). Social media as a catalyst for civil society movements in India: A study in Dehradun city. New Media \& Society, 17(8), 1299-1316

Kümpel, A. S., Karnowski, V., \& Keyling, T. (2015). News sharing in social media: A review of current research on news sharing users, content, and networks. Social Media + Society, 1(2), 1-14.

Leong, P. (2015). Political communication in Malaysia: A study on the use of new media in politics. Jedem, 7(1), 46-71.

Livingstone, S. (2014). Developing social media literacy: how children learn to interpret risky opportunities on social network sites. Communications, 39(3), 283-303.

Maamari, B. E., \& Zein, H. E. (2014). The impact of social media on the political interests of the youth in Lebanon at the wake of the Arab spring. Social Science Computer Review, 32(4), 496-505.

Marsh, H. W., \& Hau, K.-T. (1996). Assessing goodness of fit: Is parsimony always desirable? The Journal of Experimental Education, 64(4), 364-390.

Martens, H., \& Hobbs, R. (2015). How media literacy supports civic engagement in a digital age. Atlantic Journal of Communication, 23(2), 120-137.

Mihailidis, P., \& Cohen, J. N. (2013). Exploring curation as a core competency in digital and media literacy education. Journal of Interactive Media in Education, 2013(1), 2.

Hassan, M. S., Sah Allam, S. N., Azim, M/ A., M., Abdul Mutalib, M. A., Mahbob, M. H., \& Daud, M. A. (2020). Measuring the integrity of young people political participation: psychometric analysis of media literacy. International Journal of Academic Research in Business and Social Sciences, 10(2), 12-33.

Hassan, M. S., Sah Allam, S. N., Khamis, M. H., Bakar, M. H., \& Ridzuan, A. R. (2019). Perspektif literasi media aspek analisis dan penilaian: Amalan integriti penyertaan politik golongan muda di media sosial. Jurnal Sains Sosial, 4(1), 20-32.

Hassan, M. S., Sah Allam, S. N., Azni, M. Z., \& Khamis, M. H. (2013). Social media and political participation among young people. Jurnal Sains Sosial, 1(1), 95-114.

Murinska-Gaile, S., \& Hadžialić, S. (2017). Development of critical thinking skills: comparative analysis of media literacy level in Bosnia and Herzegovina and Latvia. Society. Integration. Education. Proceedings of The International Scientific Conference, 2, 504.

Naab, T. K., \& Sehl, A. (2017). Studies of user-generated content: A systematic review. Journalism, 18(10), 1256-1273.

Park, C. S. (2015). Pathways to expressive and collective participation: usage patterns, political efficacy, and political participation in social networking sites. Journal of Broadcasting And Electronic Media, 59(4), 698-716.

Parrott, E. (2017). Building political participation: the role of family policy and political science courses. Journal of Political Science Education, 13(4), 404-425.

Persson, M. (2013). Is the effect of education on voter turnout absolute or relative? a multilevel analysis of 37 countries. Journal of Elections, Public Opinion and Parties, 23(2), 111133.

Pires, F., Masanet, M. J., \& Scolari, C. A. (2019). What are teens doing with youtube? Practices, uses and metaphors of the most popular audio-visual platform. Information Communication and Society, 1-17.

Pong, T. K. (2012). Aktivisme mahasiswa cina era reformasi dan pasca reformasi Di Malaysia: 
Kajian impak politik dalam Pilihan Raya Umum Ke-12. Akademika, 82(1), 91-102.

Potter, W. J. (2004). Argument for the need for a cognitive theory of media literacy. American Behavioral Scientist, 48(2), 266-272.

Ridanpaa, J. (2014). Politics of literary humour and contested narrative identity (of a region with no identity). Cultural Geographies, 21(4), 711-726.

Rill, L. A., \& Cardiel, C. L. B. (2013). Funny, ha-ha: the impact of user-generated political satire on political attitudes. American Behavioral Scientist, 57(12), 1738-1756.

Saldaña, M., Mcgregor, S. C., \& Zúñiga. (2015). Social media as a public space for politics: Cross-national comparison of news consumption and participatory behaviors in the United States and The United Kingdom. International Journal of Communication, 9(1), 123.

Simmons, T. (2019). Media literacy and fake news. Journalism and Ethics, January, 163-176.

Sah Allam, S., N., Hassan, M. S., Azni, M. Z., \& Khamis, M., H. (2012). News Media Exposure and Political Participation Among Young People. Technology, Science, Social Sciences and Humanities International Conference 2012, 1-18.

Stockemer, D. (2012). Students' political engagement: A comprehensive study of University of Ottawa undergraduate students. Journal of Youth Studies, 15(8), 1028-1047.

Syahputra, I. (2019). Expressions of hatred and the formation of spiral of anxiety on social media in Indonesia. SEARCH Journal of Media and Communication Research, 11(1), 95112.

Taib, R., \& Yaakop, M. R. (2017). Penglibatan mahasiswa dalam protes politik di IPTA PRK 2016. Journal of Social Sciences and Humanities, 2(2), 104-115.

Tang, G., \& Lee, F. L. F. F. (2013). Facebook use and political participation: The impact of exposure to shared political information, connections with public political actors, and network structural heterogeneity. Social Science Computer Review, 31(6), 763-773.

Vainikka, E., \& Herkman, J. (2013). Generation of content-producers? The reading and media production practices of young. Journal of Audience and Reception Studies, 10(2), 118138.

Valenzuela, S. (2012). Protesting in The Age of Social Media: Information, Opinion Expression and Activism in Online Networks. Latin American Public Opinion Congress, World Association for Public Opinion Research (Wapor), July, 1-38.

Valeriani, A., \& Vaccari, C. (2016). accidental exposure to politics on social media as online participation equalizer in Germany, Italy, and The United Kingdom. New Media and Society, 18(9), 1857-1874.

Van Dijck, J. (2009). Users like you? Theorizing agency in user-generated content. Media, Culture and Society, 31(1), 41-58.

Velasquez, A. (2012). Social media and online political discussion: the effect of cues and informational cascades on participation in online political communities. New Media \& Society, 14(8), 1286-1303.

Vromen, A., Xenos, M. A., \& Loader, B. (2014). Young people, social media and connective action: from organisational maintenance to everyday political talk. Journal of Youth Studies, 18(1), 80-100.

Wan, C. Da, \& National. (2019). The universities and university colleges act in Malaysia: History, contexts and development. Kajian Malaysia, 37(2), 1-20.

Westerlund, M. (2019). The emergence of deepfake technology: A review. Technology Innovation Management Review, 9(11), 39-52.

Willnat, L., Wong, W. J., Tamam, E., \& Aw, A. (2013). Online media and political participation: 
the case of Malaysia. Mass Communication and Society 16 (4) 557-585.

Wilson, J. (2011). Playing with politics: political fans and twitter faking in post-broadcast democracy. The International Journal of Research into New Media Technologies, 17(4), 445-461.

Wolfsfeld, G., Yarchi, M., \& Samuel-Azran, T. (2015). Political information repertoires and political participation. New Media \& Society, 18 (9) 2096-2115.

Yamamoto, M., \& Kushin, M. J. (2014). More harm than good? Online media use and political disaffection among college students in the 2008 election. Journal of Computer-Mediated Communication, 19(3) 430-445.

Zhang, X., \& Lin, W.-Y. Y. (2014). Political participation in an unlikely place: how individuals engage in politics through social networking sites in China. International Journal of Communication, 8(1), 22. 